\title{
ENHANCEMENT OF DOPAMINE-INDUCED STIMULATION OF PANCREATIC SECRETION BY 5-DIMETHYLDITHIO- CARBAMYLPICOLINIC ACID (YP-279), A DOPAMINE $\beta$-HYDROXYLASE INHIBITOR
}

\author{
Kazuhiko IWATSUKI and Koroku HASHIMOTO* \\ Department of Pharmacology, Tohoku University School of Medicine, Sendai 980, Japan
}

Accepted August 28, 1978

\begin{abstract}
Effect of 5-dimethyldithiocarbamylpicolinic acid (YP-279), a dopamine $\beta$-hydroxylase inhibitor, on the secretion of pancreatic juice induced by dopamine was investigated in preparations of the isolated blood-perfused canine pancreas. Either a single injection $(300 \mu \mathrm{g})$ or an infusion $(100 \mu \mathrm{g} / \mathrm{min})$ of YP-279 intra-arterially (i.a.) caused no change in the outflow of the pancreatic juice, but the secretagogue effect of dopamine $(1-10 \mu \mathrm{g}$, i.a.) was enhanced by the infusion of YP-279 $(100 \mu \mathrm{g} / \mathrm{min}$, i.a. $)$ for $60 \mathrm{~min}$. The previous conclusion obtained with fusaric acid was confirmed as follows; the dopamine $\beta$-hydroxylase activity controls the dopaminergic mechanism of the pancreatic secretion.
\end{abstract}

Dopamine $\beta$-hydroxylase inhibitors such as disulfiram (1), fusaric acid (2) and 5-(nbutyl)-picolinamide (3) have been proved to decrease norepinephrine level while dopamine level was increased not only in the brain but also in various peripheral organs. Recently, 5-dimethyldithiocarbamylpicolinic acid (YP-279) has been synthesized and it was proved that YP-279 was a selective dopamine $\beta$-hydroxylase inhibitor and equipotent to fusaric acid in an in vitro study (4).

Previously we reported that dopamine caused an increase in the secretion of pancreatic juice in dogs but norepinephrine showed entirely no effect on the pancreatic secretion (5) and the secretagogue effect of dopamine was enhanced by the treatment of fusaric acid (6), which suggested that there were specific receptors to secrete the pancreatic juice by dopamine. Facilitation with the treatment of fusaric acid, however, raised a question since fusaric acid itself stimulated the pancreatic stimulation.

In the present study, previous results were reinvestigated by use of YP-279, a peripheral dopamine $\beta$-hydroxylase inhibitor and the role of dopamine $\beta$-hydroxylase on the pancreatic secretion was discussed.

\section{MATERIALS AND METHODS}

Six mongrel dogs of either sex, weighing 11 to $15 \mathrm{~kg}$, were anesthetized with $30 \mathrm{mg} / \mathrm{kg}$ of sodium pentobarbital given i.v. A polyethylene tube was inserted into the main pancreatic duct for collection of the pancreatic juice. Polyethylene cannulae were inserted into the

* Present address: Department of Pharmacology, Hatano Research Institute, Food and Drug Safety Center, Ochiai, Hatano, Kanagawa 257, Japan 
gastroduodenal and splenic arteries through which the pancreas was perfused with the animal's own blood from the left femoral artery by mean of a Harvard peristaltic pump (Model 500-1200). All experiments were performed under constant pressure at $100 \mathrm{~mm} \mathrm{Hg}$. Details of the preparation were described in previous papers $(5,6)$. A dose of $300 \mathrm{U} / \mathrm{kg}$ of sodium heparin was given at the beginning of the perfusion and a supplementary dose of 2,000 units was given i.v. Drugs used were dopamine hydrochloride (ICN) and 5-dimethyldithiocarbamylpicolinic acid (YP-279, kindly provided by Prof. H. Hidaka, Mie University Medical School). Drugs were dissolved in $0.9 \%$ saline solution and were injected or infused into a rubber tube connected to the arterial cannula. Statistical analysis was made by means of Student's $t$-test.

\section{RESULTS}

Either a single injection $(300 \mu \mathrm{g})$ or an infusion $(100 \mu \mathrm{g} / \mathrm{min})$ of YP-279 i.a. produced no change in the outflow of the pancreatic juice. Dopamine $(1,3$ or $10 \% \mathrm{~g})$ i.a. caused an increase in the secretion of the pancreatic juice as reported previously (5). The dopamineinduced pancreatic secretion was significantly enhanced by treatment with YP-279 $(100 \mu \mathrm{g} /$ min) for $60 \mathrm{~min}$. Table 1 shows the results obtained in 6 dogs.

TABLE 1. Effect of YP-279 infusion on the secretion of pancreatic juice induced by dopamine

\begin{tabular}{|c|c|c|c|}
\hline \multirow{2}{*}{$\begin{array}{l}\text { Dose of } \\
\text { dopamine }\end{array}$} & \multirow{2}{*}{$\begin{array}{c}\text { No, of } \\
\text { experiments }\end{array}$} & \multicolumn{2}{|c|}{ Volume of pancreatic secretion $(\mu 1)$} \\
\hline & & Control & YP-279 infusion for $60 \mathrm{~min}$ \\
\hline $1 \mu \mathrm{g}$ & 6 & $76 \div 13$ & $113.14^{*}$ \\
\hline $3 \mu \mathrm{g}$ & 6 & $310 \pm 52$ & $483 \cdot 35^{*}$ \\
\hline $10 \mu \mathrm{g}$ & 6 & $961+65$ & $1240.56^{*}$ \\
\hline
\end{tabular}

YP-279 was infused at a rate of $100 \mu \mathrm{g} / \mathrm{min}$ and dopamine $(1,3$ and $10 \mu \mathrm{g})$ was injected intra-arterially. Each value represents the mean \pm s.e.m. Significance of difference $\mathrm{P}<0.05\left(^{*}\right)$

\section{DISCUSSION}

Previously we observed similar results that dopamine-induced pancreatic secretion was enhanced by fusaric acid, although fusaric acid itself stimulated pancreatic secretion (6). The enhancement caused by fusaric acid $(100 \mu \mathrm{g} / \mathrm{min})$ was significant $30 \mathrm{~min}$ after the infusion $(\mathrm{p}<0.05)$ and highly significant $60 \mathrm{~min}$ after the infusion $(\mathrm{p}<0.01)$. The potency of YP-279 required to enhance dopamine-induced secretion in vivo was less than that of fusaric acid. Hidaka et al. (4) have reported that YP-279 is equipotent with fusaric acid as an inhibition of dopamine $\beta$-hydroxylase in vitro, but its in vivo inhibitory activity is less potent than that of fusaric acid. The potency of these drugs for enhancement of the pancreatic secretion may then be correlated with the potency of dopamine $\beta$-hydroxylase inhibition in vivo.

There is much evidence supporting the role of dopamine $\beta$-hydroxylase in the biosynthesis of catecholamine at the adrenergic nerve terminals, and such was also confirmed by Symchowicz et al. (7) in the pancreas. On the other hand, Alm et al. (8) observed by use of 
a specific fluorometric method that L-dopa and dopamine were taken up in the acinar cells of the rat pancreas and once accumulated in the granules in these cells, the characteristic fluorescence faded gradually and finally disappeared. They did not report the effect on the exocrine pancreas of L-dopa and dopamine. We examined the effects of various pharmacodynamic agents on the exocrine secretion of the canine pancreas (9) and further analysed the specific stimulatory effect of dopamine and L-dopa (10). We obtained the following results: 1) L-dopa and dopamine stimulated the secretion of pancreatic juice, while norepinephrine and epinephrine did not. 2) Ro 4-4602 (benserazide), an L-aromatic amino acid decardoxylase inhibitor, blocked the stimulatory effect of L-dopa while dopamine was not modified by this treatment. 3) The effect of either L-dopa or dopamine was significantly attenuated by haloperidol, a dopamine receptor antagonist. 4) The content of bicarbonate was high in the dopamine-induced pancreatic juice while the protein content was low, this response being similar to that seen with secretin. This observation confirmed the site of dopaminergic receptors at the ductural cells. 5) Stimulation of the secretion of pancreatic juice induced by L-dopa showed a definite delay in initiation of the response, thus suggesting the conversion of L-dopa to dopamine in the ductural cells. It is interesting to speculate whether or not dopamine is converted to norepinephrine in the ductural cell which may control the secretagogue effect of dopamine. Fusaric acid enhanced the stimulatory effect of dopamine, while fusaric acid itself had a definite stimulatory effect on the pancreatic secretion. YP-279, a selective inhibitor of peripheral dopamine $\beta$-hydroxylase, had no stimulatory effect on the pancreatic secretion but definitely enhanced the dopamine-induced pancreatic secretion, in this study. These results suggest that the dopamine $\beta$-hydroxylase activity in the pancreas controls the dopaminergic mechanism of the pancreatic secretion in dogs.

\section{REFERENCES}

1) Goldstein, M. and Nakajima, K.: The effect of disulfiram on catecholamine level in the brain. J. Pharmacol. exp. Ther. 157, 96-102 (1967)

2) Nagatsu, T., Hidaka, H., Takfya, K., Umfzawa, H., Takeuchi, T. and Suda, H.: Inhibition of dopamine $\beta$-hydroxylase by fusaric acid (5-Butylpicolinic acid) in vitro and in vivo. Biochem. Pharmacol. 19, 35-44 (1969)

3) Korduba, C.A., Veats, J., Wohl, A., Symchowicz, S. and Tabachnick, I.I.A.: SCH 10595 , an effective dopamine $\beta$-hydroxylase inhibitor and a hypotensive agent. J. Pharmacol. exp. Ther. 184, 671-677 (1973)

4) Hidaka, H., Hara, F., Harada, N., Hashizume, Y. and Yano, M.: Selective inhibition of dopamine-beta-hydroxylase in the peripheral tissues by 5-dimethyldithiocarbamylpicolinic acid, its effect on stress-induced ulcer, ethanol-induced sleep and blood pressure. J. Pharmacol. exp. Ther. 191, 384-392 (1974)

5) Hashimoto, K., Satoh, S. and Takeuchi, O.: Effect of dopamine on pancreatic secretion in the dog. Brit. J. Pharmacol. 43, 739-746 (1971)

6) Furuta, Y., Hashimoto, K., IWATSUki, K. and Takeuchi, O.: Effects of enzyme inhibitors of catecholamine metabolism and of haloperidol on the pancreatic secretion induced by L-dopa and dopamine in dogs. Brit. I. Pharmacol. 47, 77-84 (1973)

7) Symchowicz, S., Korduba, C.A., Veals, J. and Tabachnick, I.I.A.: Norepinephrine biosynthesis in the rat pancreas. Biochem. Pharmacol. 17, 2313-2317 (1968)

8) Alm, P., Ehinger, B. And Falck, B.: Histochemical studies on the metabolism of L-dopa and some related substances in the exocrine pancreas. Acta physiol. scand. 76, 106-120 (1969) 
9) Takeuchi, O., Satoh, S. And Hashimoto, K.: Secretory and vascular response to various biogenic and foreign substances of the perfused canine pancreas. Japan. J. Pharmacol. 24, 57-73 (1974)

10) Hashimoto, K.: DOPA and pancreatic secretion. Frontiers in Catecholamine Research, p. 67-70, Pergamon Press, Oxford (1973) 